\title{
POLAND IN ECONOMIC PURSUIT OF THE WEST
}

\section{ANNA SOSNOWSKA, EXPLAINING ECONOMIC BACKWARDNESS: POST-1945 POLISH HISTORIANS ON EASTERN EUROPE}

Marcin Kawko

Warsaw School of Economics

The book Explaining Economic Backwardness: Post-1945 Polish Historians on Eastern Europe by Anna Sosnowska is an extensive work in the field of historical sociology. The author is a sociologist working at the University of Warsaw's American Studies Center and studying the impact of migration from Eastern Europe and other peripheral countries on the development of American cities in post-industrial times. Before the publication of the work reviewed in this article, she published two books in Polish: Polski Greenpoint a Nowy Jork. Gentryfikacja, stosunki etniczne i imigrancki rynek pracy na przetomie XX i XXI wieku [Polish Greenpoint and New York: Gentrification, ethnic relations, and the immigrant labour market at the turn of the twentieth and twenty-first centuries] and Zrozumié́ zacofanie. Spory historyków o Europe Wschodniq (1947-1994) [Understanding backwardness: Historians' disputes over Eastern Europe (1947-1994)]. Explaining Economic Backwardness is an updated translation of the latter. ${ }^{1}$

Sosnowska's book describes the post-war debate between Polish social and economic historians over the sources of Poland's - and more broadly,

\footnotetext{
${ }^{1}$ In the English-language translation, a short subchapter on religion was removed and examples referring to the contemporary political scene in Poland were added.
} 
Eastern Europe's - economic backwardness. Apart from trying to identify the sources of backwardness in this region, Sosnowska tries to answer the question of the extent to which backwardness in Central and Eastern Europe is specific to the region, and to what extent it can be compared with backwardness in other parts of the world.

The core of the work are the models of backwardness of Eastern Europe proposed by the most important post-war researchers of Polish socio-economic history: Marian Małowist (1909-1988), Witold Kula (19161988), Jerzy Topolski (1928-1998), and Andrzej Wyczański (1924-2008), as well as some of their students. The boundary works in Sosnowska's analysis are Kula's habilitation lecture in 1947, "Social Privilege and Economic Progress," and Topolski's book entitled Polska w czasach nowożytnych. Od środkowoeuropejskiej potegi do utraty niepodlegtości (1505-1795) [Poland in modern times: From Central European power to the loss of independence (1505-1795)], which was published in 1994.

\section{/// A Broad Discussion of the Causes of Backwardness}

The book consists of five chapters in which the theoretical background is established first and then the models themselves and their implications are provided. Chapters 1 and 4 present specific models created by foreign and Polish authors, respectively. Among the foreign authors, Sosnowska discusses the works of such researchers as Immanuel Wallerstein, Iván T. Berend and György Ránki, Fernand Braudel, Robert Brenner, Perry Anderson, and Jenő Szücs. In the second chapter, Sosnowska presents four major Polish social historians, whose debate she later analyses. Both the detailing of the political and social background in which they worked and their relationship with Marxism are extremely valuable for understanding the perspective of these scholars. Thus, the reader learns that Małowist, Kula, and Topolski were not only closely connected with Marxism in the ideological sense but also partially cooperating with the state apparatus. Sosnowska notes that for this very reason these authors were excluded from the post-transformational debate on the sources of Poland's backwardness. Sosnowska becomes a kind of advocate for these scholars, explaining that, first, they worked in specific times and in a specific place (unlike, e.g., Oskar Halecki, who was writing in the United States), and second, the social sensitivity of Małowist and Kula was determined by the effects of the Great Depression in the years 1929-1933. The Marxist approach appears 
throughout Sosnowska's entire work, as will be noticeable in the models created by the Polish historians.

In the third chapter, Sosnowska analyses the geographical terms used in Polish and global models of backwardness in Eastern Europe in more detail. At the beginning, she emphasises that she uses the hermeneutics of suspicion (Sosnowska 2019: 105) - which can be reduced to the assumption that the historians consciously and intentionally used specific geographical concepts. In her opinion, semantics is of considerable importance as it defines the perspective from which the region is presented in relation to other parts of the world - primarily Western Europe. It does seem worthwhile to go beyond the division of Europe into West and East, as defined at Yalta. In this part of the book, we learn how the geographical region of which Poland is an immanent part is perceived as being Slavic, Mittel, Central, or East-Central European. Each of these concepts has specific geopolitical implications, which are both historical - for instance, Mitteleuropa as a concept used by the Nazis - and closer to the present day: Slavic Europe as a myth serving to expand the influence of the Russians; or Central and Eastern Europe as an attempt at a post-transformational tearing away from the Soviet sphere of influence, while emphasising the European character of the region.

The last - fifth - chapter, "Explaining Economic Backwardness," is a combination of summary and a selection of the book's key theses concerning research on the social structure. This part of the work outlines the broadest perspective, as Sosnowska goes beyond the Kula and Małowist schools to refer to the works of a dozen other scholars. The entire chapter is an analysis of Polish social groups and institutions engaged in or affected by the backwardness of Eastern Europe (the so-called agents of backwardness), through the prism of two concepts introduced by Kula, that is, "rentiers of backwardness" and "pioneers of progress" (Kula 2001 [1963]: 578), and one added by Sosnowska: "victims of backwardness" (Sosnowska 2019: 243).

The first part of the fifth chapter analyses the debate by Małowist and Wyczański on the role of farms in the development (or rather progressive backwardness) of Polish society. In his model, Małowist assumes that the institution of the folwark, which eliminated the culture-creating role of the cities and the social role of the state, contributed permanently to the backwardness of the inhabitants of Polish lands. He argues that the nobility and Western immigrants were the main rentiers of the farm system, with the peasants being its greatest victims. Wyczański disagrees with this ap- 
proach, noting that the financial situation of the peasants in the sixteenth century improved significantly and working in the folwark system was their deliberate choice. According to Wyczański, it was a choice dictated by the need for security, which he contrasts with the situation of the peasantry in Western Europe, where peasants who had their own farms often went bankrupt and incurred huge debts towards the upper social classes.

The above dispute perfectly outlines the core of the debate analysed by Sosnowska. Both later in chapter 5 , where she describes the development of towns and villages, the situation of the peasants and nobility, the role of western immigrants and the implications of the emergence of new social strata (i.e., the intelligentsia and the bourgeoisie), and in the rest of the work, one side of the debate is formed by Kula, Małowist, and their students, and the other side by Wyczański and Topolski. While according to Kula and Małowist, Eastern Europe has always been a kind of periphery of more developed civilisations, both Wyczański and Topolski believed that it is possible to point to a period in Poland's history when the Commonwealth was as highly developed as its European trading partners. In general terms, the first two historians can be called pessimists, and the other two represent the so-called optimistic approach in Polish historiography (Sosnowska 2019: 82).

\section{/// The Backwardness of Eastern Europe in the Eyes of Foreign Social Researchers}

However, in order to be able to analyse the models proposed by Małowist, Kula, Topolski, and Wyczański, it is worthwhile first briefly to present the international debate that has been underway for several decades over the backwardness of Eastern Europe. Sosnowska emphasises several times in her work that this debate takes the form of a tension between Weberism and Marxism. While the first view is based on the cultural factors for a society's development, Marxism is based on the principles of historical materialism. Both in Poland and elsewhere, it was Marxist materialism that defined the debate about the reasons for the backwardness of some countries (Sosnowska 2019: 104).

In the context of the backwardness of the world's poorer regions, the most frequently analysed issue is the social structure, which is perceived through the prism of class struggle. It is almost as common to attribute the consolidation (and often creation) of backwardness to capitalism. This is how Wallerstein created his world-systems theory. In his model, it was 
capitalism that made the wealthy countries develop earlier and subjugated other regions, which he called the periphery. The powers belonging to the first group deliberately act in such a way as to subdue poorer countries and to be able to derive tangible benefits from this relationship of power. Importantly, Wallerstein saw the economy as a zero-sum game, so in order for powers to become richer, the poorer must lose. In this model, Eastern Europe - along with Latin America - is the first periphery of the system, whose heart is Western Europe. Wallerstein considered the reasons for this state of affairs to be the poor development of Eastern European cities in the sixteenth century, the lower population density in these lands - which meant that landowners had no impulse to innovate - and the Turk and Tatar invasions which devastated the eastern part of Europe towards the end of the Middle Ages (Wallerstein 1974: 98). The Hungarian historians Iván T. Berend and György Ránki (Berend \& Ránki 1982, quoted in Sosnowska 2019: 34) applied the Wallerstein model directly to the realities of Central and Eastern Europe.

The concept of the peripheral nature of Eastern Europe was also developed by Fernand Braudel of the Annales school in Paris, who noticed the positive sides of capitalism (flexibility in terms of investment and divestment) but at the same time blamed it for increasing the differences between the rich and the poor. Capitalists, as the highest form of socioeconomic development, were assumed to break the laws of the market by taking advantage of their greater knowledge, creating monopolies, and using numerous sources of credit and asymmetrically distributed information (Braudel 1992: 455). What distinguishes Braudel's model from Wallerstein's is the identification of the main actors in the above process. While Wallerstein considered that the great owners of land and industry were the "exploiting class" (in line with Marxist theory), Braudel assigned this role to Western merchants monopolising the grain trade in Eastern Europe. Thus, it is not capitalism itself that is to blame for backwardness, but rather its misuse by merchants, who had subordinated the producers to themselves (Braudel 1992: 272).

The other researchers mentioned by Sosnowska had a slightly different perspective. Robert Brenner makes the contrarian claim that development is something extraordinary, while underdevelopment and stagnation are ordinary states. Thus, differences in economic development depend on many convergent factors that may occur in some countries and not in others. Even more original is Perry Anderson, who attributes the development of capitalism in Western Europe to the Roman-Germanic legacy and to the 
complexes Western Europeans acquired due to the devastation of Roman culture by the Germanic tribes.

In summarising the international debate, Sosnowska notes that the backwardness of Eastern Europe has been analysed in the West mainly through the prism of the development of the West itself and the emergence of capitalism. In her opinion, Western sociologists have always treated the development of Western Europe as something special. Central Europe, on the other hand, is not perceived by them as a backward version of the Western path but as a backward region that did not choose this path (for various reasons - failure to follow suit, historical backwardness, peripheral status). The factors of perpetuating backwardness most frequently cited in the international debate are population density (mainly in rural areas), relations between the nobility and peasants, and the very fact of the existence of serfdom in Eastern Europe.

\section{/// Polish Models for the Economic Backwardness of Eastern} Europe

It is not without reason that the perspective of the Polish authors coincides with that of the international debate. Wallerstein referred in his work, inter alia, to Małowist's model, while Kula (and his students) collaborated with the Braudel school. It can thus be said that Western sociologists in some way adapted the models that previously existed in the debate between Polish social historians. Sosnowska's analysis in chapter 4 of the discussion that took place in post-war Poland is thus all the more valuable.

The first model Sosnowska presents is the model of colonial development that Marian Małowist proposed in a work published in 1973, Wschód a zachód Europy w XIII-XVI wieku. Konfrontacja struktur spoteczno-gospodarczych [East and West Europe in the thirteenth-sixteenth centuries: A confrontation of socio-economic structures]. Due to Wallerstein's later adaptation of the model, it can be concluded that the Małowist theory is still the most widespread view on the causes of Poland's backwardness before 1989. As the name suggests, the Małowist model is based on the colonial subordination of poorer countries to richer countries, that is, those which developed a capitalist system earlier. Małowist claimed that the differences that arose in the sixteenth century contributed to the perpetuation of backwardness in Eastern Europe and that the differences were brought about by the specialisation of production in the European market. He was later criticised 
by other scholars for not having analysed the short-term benefits that that specialisation brought to Poles.

In the second half of the fifteenth century, when Western Europe was consumed by a great socio-economic crisis, merchants sought new markets where they could acquire the necessities for their economies: wood, flax, cattle, grain, and minerals. Among other places, the lands of modern Poland came to be such a market. The local nobility noticed that they could get rich relatively quickly from the grain trade, and therefore they began to intensify production in that branch of the economy. In this way, a specific production monoculture was created, which made Eastern Europe responsible for supplying raw materials to Western Europe. The inhabitants of richer countries could focus on the development of more efficient branches of the economy - crafts and trade - and, consequently, start non-European colonial conquests.

The system constructed in this way meant that the Polish nobility, motivated by huge profits, sought to expand the scope of serfdom among the peasants. Despite the initial development of crafts (thanks to increasing incomes), at the turn of the fifteenth to sixteenth centuries the cities began to decline as the internal demand for their inhabitants' goods decreased: the peasants were losing land, which was incorporated into the farms of the nobility, so they could not afford excess consumption. The key factor for the Małowist model is the fact that the Polish nobility did not use the cash they raised to invest in greater productivity but rather increased their consumption of luxury goods imported from the West. In the seventeenth century, however, the system collapsed as wealthy countries in Western Europe imported raw materials from the colonies, reducing demand in the Eastern European markets. The weakness of the central government, which was unprecedented in the West, was an additional factor contributing to the crisis: the wealthy nobles had won enormous privileges for themselves and became virtually uncontrollable. Thus, in the sixteenth century, the folwark and serf-based economy began the division of Europe, which would deepen in the following centuries.

Andrzej Wyczański did not agree with such a pessimistic vision of Poland in the sixteenth century. As a historian specialising in the sixteenth century - Poland's "golden" age - he proposed a model in opposition to the "colonial model," one of "catching up with Europe." He admitted that in the sixteenth century Poland and its neighbours were backward in relation to the countries of Western Europe, but many economic and social factors prove that these countries were on their way to "catching up" 
with the so-called West. It is worth noting here that despite Wyczański's repeated denial of Marxist doctrines, the core of his model is evolution. Accordingly, there is one - linearly defined - path of development that all societies follow.

Wyczański believed that the reason for Poland's temporary backwardness was its later adoption of Christianity, which allowed it to join Latin civilisation only at the turn of the tenth and eleventh centuries. It was, however, already at a quite average level of development for Europe, as shown by both the economic indicators (the amount of crops, the level of material culture, a general monetary system, and the percentage of the population "employed" outside agriculture) and the social indicators (law, education - parish schools and Jagiellonian University, which had extensive contacts with Italian universities). The data for the areas of the Crown, which was well developed, are particularly suggestive. The Grand Duchy of Lithuania, which was attached to the Commonwealth, had slightly different characteristics. Wyczański explained the country's agricultural monoculture by the fact that grain was a commodity that could be effectively produced in Poland. Thus, we see in Wyczański's model a reference to David Ricardo's classic theory of comparative advantage, which says that states need to specialise in the effective production of specific goods ( $\mathrm{Ri}$ cardo 1817).

In spite of effective economic development, the Polish nobility did not adopt the Western social model. The increase in demand for the production of Polish grain thus entailed the intensification of serfdom instead of the freeing of the peasants and turning them into farm tenants, as happened in the West. The standard of living of the nobility was comparable to that of their European counterparts, but the property and social gap between the nobility and the peasantry grew disproportionately, in contrast to Western Europe, where capitalism began to develop and, in connection, the peasantry was liberated (Wyczański 1987: 79). According to Wyczański, the reason for the backwardness of Poland and its neighbouring countries was therefore their effective catching up with Western Europe in terms of economic development, with their simultaneous failure to adopt the Western social structure.

Sosnowska's next protagonist, Jerzy Topolski, agreed with Małowist that the difference between the East and West of Europe arose at the turn of the Middle Ages and early modern times and was expressed primarily in the relationship between the nobility and peasants. Only in Eastern Europe was a system adopted in which the peasants were still subjects of the 
upper classes, whose wealth was increasing. However, Topolski's model is distinguished from Małowist's by the much lower weight that Topolski assigned to trade relations with Western buyers. According to him, the key to understanding Polish backwardness is the social structure of Poland in the sixteenth century. Moreover, it is not without reason that Topolski calls his model "an unfortunate set of historical circumstances," as he introduces the breakdown of international trade caused by the import of raw materials from European colonies as a significant variable, and - more importantly - the consequences of the numerous wars that consumed the Commonwealth in the sixteenth and especially the seventeenth century. The core of Topolski's model thus centres on social relations, the strength and mentality of the magnates, the weakness of the peasantry, and external economic and political events.

In analysing the situation of the nobility and peasants in Wielkopolska, Topolski opposes Małowist and Kula. He believes that the majority of the nobility in Wielkopolska was of middling wealth, producing for the local market and not, as Małowist suggests, solely for export. The entrepreneurial attitude of members of the upper class allowed them to create a quasi-capitalist system in which a landowner would own as many farms as he was able to manage effectively (Topolski 1977: 267-281). Topolski's distinctiveness was undoubtedly influenced by the fact that he was the only one of the four historians to be from outside the Warsaw community: he worked at the Adam Mickiewicz University in Poznań. However, this does not diminish the importance of the fact that the nobility of Greater Poland (and Pomerania) displayed much more entrepreneurial attitudes than members of their class living in other parts of the Commonwealth.

Sosnowska devotes the most space in her book to Witold Kula's model of hybrid development. Its complexity, which was noticed among others by Braudel, allowed Kula to include in his analysis both social and cultural factors (as did Topolski and Wyczański), as well as external factors (as did Małowist). The essence of the Kula model is to point to the destructive role of the folwark system, especially in the degradation of cities, which in Western Europe were a culture-creating form of social organisation. In developing the folwark-serf model of the economy, the Polish nobility used the money they earned from the grain trade for the consumption of Western luxury goods. Thus, capital was not accumulated and reinvested locally but flowed back to the West.

In addition, the great folwark farms built in Poland tried to be selfsufficient and therefore did not participate in the market trade. Instead of 
capitalist proto-enterprises, they became feudal organisations using free - serf - labour. The estates organised in this manner grew rich on foreign trade, while the smaller peasant farms produced only to meet their basic nutritional needs. In this way, a dual economy developed in Eastern Europe (a generalised term, as Kula's analyses covered solely Polish lands).

Trading conditions are crucial for the Kula model. Due to the high demand for Polish grain on European markets, the large folwark owners had the best bargaining position. With time, the difference between the various classes of Polish society began to grow in terms of the conditions that their members obtained in relations with Dutch merchants. The impoverished peasants were reduced to misery, which in turn limited internal demand. The trade structure, which was focused on exports, collapsed in the seventeenth century with the influx of goods from European colonies, and this ultimately led to the collapse of the Polish economy (Kula 1976: 132-133).

Kula's model can be called hybrid for two reasons. First, he includes in his analysis both external criteria (trade conditions) and internal criteria (the social structure). Second, he takes into account not only economic indicators, but also "humanist" indicators, such as average life expectancy, which is still one of the key criteria in assessing the level of development of countries (Sosnowska 2019: 233).

In summarising the models of the four most important post-war social historians in Poland, Sosnowska notes that all four models place the development of Eastern Europe in opposition to that of Western Europe. In common, they locate the causes of Poland's backwardness, which started at the end of the sixteenth century, in the country's social structure, the polarisation of the income structure (and assets), and citizens' rights. However, the Polish historians do not agree on the economic indicators used. For Małowist and Kula, the crux of the problem lay in relations with Western European merchants (for Małowist, in asymmetry in trade, and for Kula, in trade conditions), while Wyczański and Topolski attached greater importance to political and cultural factors (Wyczański to the role of the state, and Topolski to the mentality of the gentry).

\section{/// Advantages and Disadvantages of a Sociological Historiographic Analysis}

The presence of the word "economic" in the title of Anna Sosnowska's book seems to suggest to the reader that economic issues will be addressed at length. The work is a broad - and therefore quite general - presenta- 
tion of models constructed by historians who, with one exception (Witold Kula), had not received an education in economics. A reader with an expectation of a broader economic analysis dealing with the subject of - economic, after all - backwardness, for example, in connection with the highly developed quantitative models of Robert W. Fogel, winner of the Nobel Prize (see, e.g., Fogel 2014 [2000]), or the in-depth analysis of the literature by Tomáš Sedláček (see Sedláček 2012 [2009]), may be disappointed. Sosnowska is a sociologist, not an economist, and therefore in her book she presents the problem from the perspective of a sociologist. In terms of economics, one valuable aspect of the work is the correct and quite frequent use of economic terms, such as economic growth, capitalism, production, trade, profit, or competitive advantage. It is also worth remarking that the author herself summarises the problem, writing that "the language used by my protagonists treats economics as one of the social sciences, and not (solely) a set of objective mathematical models" (Sosnowska 2019: 312). While one might agree with this perception of contemporary economics, in the work itself it is difficult to find any in-depth economic analysis of the phenomena presented.

The methodological differences and variety of views among the authors analysed are another noteworthy element of Sosnowska's work. Wyczański himself accused Małowist of referring in his research to legal documents instead of to the actual state of Polish society in the sixteenth century, as illustrated, for example, by the economic indicators that he, Wyczański, gave. Topolski did not agree with Małowist on a slightly different matter: while Małowist presented Mikołaj Rej as the archetype of the Polish nobility's desire for a quiet, idyllic retirement in the countryside, Topolski spoke of the Protestant "spirit of capitalism" informing Rej's entrepreneurial activity (Sosnowska 2019: 262-263). The divergence in the time period and thematic scope of the four historians' research is also worth noting. Małowist studied the economic and social structure of Europe, Topolski and Wyczański studied national communities, and Kula focused on the production and distribution of income in Poland. Sosnowska, however, quite skilfully explains such a procedure, noting that all their analyses cover - if from different angles - the sixteenth century, which is the most important period for the subject of the book; all four also deal with the topic of social stratification, which is ultimately the major reason for Poland's backwardness in Western Europe.

The historical relativism manifested in the works of Małowist, Kula, Topolski, and Wyczański can be regarded as both a negative and, in a sense, 
positive argument. The perspective they adopted is a kind of transfer of the post-Yalta order onto the social relations that prevailed in Europe over 400 years earlier. Sosnowska notes that such presentism is a common danger for research conducted within the frame of historical sociology. Sociologists are looking for historical reasons for the phenomena they encounter today and which they consider to be the most important, and this leads to the adoption of a teleological concept: the studied phenomena had to have effects in the past and in the future, which we do not fully know (Sosnowska 2019: 303-304). It is noteworthy that all four historians changed their models with the development of social history. They did so both because they tried to broaden their perspectives and for purely utilitarian reasons, such as adjusting to the post-transformational debate in Polish historiography.

Among the undoubted merits of Explaining Economic Backwardness are the author's rejection of a popular presentation of events and facts in favour of the methodology used in sociology; the extension of the debate on backwardness to include the voices of poets and writers, such as Czesław Miłosz and Milan Kundera; an interestingly presented chronology of exchanges and changes of views, including under the influence of foreign academic discourse, for example, Topolski was the only one of the four historians to take an active part in reformulating the paradigm in historical sociology (Sosnowska 2019: 156, 214); numerous references to the works of other authors analysing the theories and models of the four main historians (e.g., Jerzy Kłoczowski, Jacek Kochanowicz, Henryk Samsonowicz, or Benedykt Zientara); and the linking of works concerning the living conditions of sixteenth-century Europe with contemporary phenomena. The latter is best illustrated in the Małowist model (profits were siphoned from Poland by foreign merchants) and in the Topolski model (the optimal size of the enterprise was of key importance for the economy, enabling it to be managed in such a way that it was possible to identify the people responsible for economic decisions - Sosnowska 2019: 266). In addition, it is also worth mentioning the advantages of the works of the protagonists of Sosnowska's book, including the multi-factorial nature of their models, which take into account such criteria as the economy, social structure, law, and demography, as well as diplomacy and the international position of the state, and, partially at least, culture, education, art, and religion, and the application of Polish models to a wider reality, as is visible, for example, in the adoption of the Małowist model by Wallerstein and the Kula model by Braudel. 
After presenting the advantages and disadvantages of Sosnowska's work, it is impossible not to refer to the key issue for the structure and the whole concept of the book, namely Marxism and its influence on the works of the authors Sosnowska analyses. In the very first pages, she refers to the claim that the four historians' research was lacking due to communist censorship. As Krzysztof Brzechczyn noted in his review of the Polish edition of Sosnowska's book:

The aftermath of the Second World War, in the form of the Yalta division, which persisted until 1989, meant that, at least in our part of Europe, the debate on the causes of economic backwardness had to take place in a more or less ideologised Marxist language in order to reach wider intellectual and social circles. After all, the elimination of historical backwardness was one of the important propaganda arguments justifying the installation of communist systems in the eastern part of Europe and giving legitimacy to their exercise of power (Brzechczyn 2007: 255).

Sosnowska clearly emphasises that she does not agree with the view which was popular in Poland after 1989 - that the only source of Poland's backwardness was socialism and central planning, and that social researchers functioning within the system were completely tarnished by it. As an argument, she cites the breadth of analyses by the Polish historians, their impact on the research of great world sociologists (including the cooperation of the Kula and Małowist schools with scholars developing Wallerstein's and Braudel's theories) and the quality of the explanations for the backwardness of Eastern Europe characterising the Polish historians' models.

In regard to the influence that Marxism had on Małowist, Kula, and Topolski, the author admits that such an influence was significant. However, these authors were not dogmatists and nor was there any great opportunism in their activities. They rather referred to Marxist theory and methodology. The issue of opportunism, however, is debatable after reading Sosnowska's work, from which we learn that these three historians more or less actively collaborated with the communist state apparatus (or, as in the case of Topolski, were an immanent part of it - Sosnowska 2019: 100). According to Sosnowska, the relations of the three historians with the communists were the reason why their models were excluded from the historical debate that occurred in Poland after 1989. However, as they 
were supposedly excluded by some very enigmatic "salon" (Sosnowska 2019: 96), it is difficult to evaluate the allegation.

In concluding the subject of Marxism, it is worth commenting on the analyses and works themselves of Małowist and Kula. Despite adopting a deeply Marxist narrative, Sosnowska has ignored two inaccuracies that emerge from the models of these two historians. In analysing economic reality through the prism of class struggle, Małowist did not seem to notice that the isolated specialisation of Polish villages, which he believed occurred in the eleventh and twelfth centuries and which he himself described as highly negative, was also an economic emanation of Marxist central planning. The effects of that specialisation, which went beyond the eleventh and twelfth centuries and are still visible in contemporary Poland, were even criticised by Kula, who was inspired by Marxism, in noticing that the post-war industrialisation of socialist Poland was not successful despite the noticeable increase in the number and size of production plants. That industrialisation had not entailed social change: instead of opening Polish society to contact with foreign countries, with the related mobility, it had done the opposite - it had closed Poland to the West, using extremely harmful isolation practices (Sosnowska 2019: 230).

However, Marxism is not directly the subject of Sosnowska's study, and therefore this topic should be treated rather as adding a certain hue to the discussion. In general, apart from the few above-mentioned inaccuracies and a number of fairly controversial theses in regard to the weaknesses of the Second Republic, the ascribing of class differences to a so-called Catholic mentality (Sosnowska 2019: 306), or the comparison of contemporary nationalist movements to German Nazism (Sosnowska 2019: 311), Sosnowska's work is an unusually wide-ranging project. It is worthy of attention for the number of works by Polish post-war social historians it analyses, as well as for its (successful) attempt to juxtapose the debate within communist Poland with the discussion on the same subject that took place outside its borders.

Explaining Economic Backwardness is therefore a work worth recommending, in which the reader will find answers to many questions related to the causes and consequences of the backwardness of Eastern Europe, which can be considered to have begun in the sixteenth century, a period commonly referred to in Polish history as having been "golden." The book's presentation of the debate between Polish social historians also makes readers aware that the post-war era was not a lost time for Polish social scientists. The sociological models they created gained the recognition of 
international scholars and, on the one hand, allowed the question of the economic and social backwardness of Eastern European countries to be considered in the international scholarly debate, and on the other hand, meant that the contours of this debate were to a certain extent outlined by native historians. Sosnowska's work is not only a summary of their achievements, but also a synthesised list of the issues and problems that have not been clearly explained in historiography until today.

Translated by Michelle Granas

Bibliography:

/// Berend I., Ránki G. 1982. The European Periphery and Industrialization 1780-1914, Cambridge University Press.

/// Braudel F. 1992. Civilization and Capitalism, 15th-18th Century, 3 vols., University of California Press.

/// Brzechczyn K. 2007. "Modele zacofania a transformacja w Europie Wschodniej,” Ruch Prawničy, Ekonomicæny i Socjologicæny, vol. 1, pp. 255-263.

/// Fogel R.W. 2014 [2000]. The Fourth Great Awakening and the Future of Egalitarianism, transl. A. Solek, University of Chicago Press.

/// Kula W. 1976. An Economic Theory of the Feudal System: Toward a Model of the Polish Economy 1500-1800, transl. L. Garner, New Left Books.

/// Kula W. 2001 [1963]. The Problems and Methods of Economic History, transl. R. Szreter, Ashgate.

/// Małowist M. 1973. Wschód a zachód Europy w XIII-XVI wieku. Konfrontacja struktur spoteczno-gospodarczych, Państwowe Wydawnictwo Naukowe.

/// Ricardo D. 1817. On the Principles of Political Economy and Taxation, John Murray.

/// Sedláček T. 2012 [2009]. Ekonomia dobra i zła. W poszukiwaniu istoty ekonomii od Gilgamesza do Wall Street, transl. D. Bakalarz, Studio Emka.

/// Sosnowska A. 2005a. "Models of East European Backwardness in Post-1945 Polish Historiography," East Central Europe, vol. 32, pp. 125-145. 
/// Sosnowska A. 2005b. Zrozumieć zacofanie. Spory bistorylów o Europe Wschodnia (1947-1994), TRIO.

/// Sosnowska A. 2016. Polski Greenpoint a Nowy Jork. Gentryfikacja, stosunki etniczne $i$ imigrancki rynek pracy na przetomie XX $i$ XXI wieku, Wydawnictwo Naukowe Scholar.

/// Sosnowska A. 2019. Explaining Economic Backwardness. Post-1945 Polish Historians on Eastern Europe, CEU Press.

/// Topolski J. 1977. Gospodarka polska a europejska w XVI-XVII wieku, Wydawnictwo Poznańskie.

/// Wallerstein I. 1974. The Modern World System: Capitalist Agriculture and the Origins of the European World Economy in the Sixteenth Century, Academic Press. /// Wyczański A. 1987. Dogonić Europe, czyli Polska w czasach Zygmunta I (1506-1548), KAW.

/// Marcin Kawko - graduate of finance and accounting, PhD student in economics at the Institute of Enterprise at the Warsaw School of Economics, social activist, member and participant of the Catholic Intelligentsia Club, publicist at the Jagiellonian Club. His research interests focus on business ethics, civil economy, relational goods, and family business. He works at the junction of business theory and practice.

ORCID: https://orcid.org/0000-0002-1493-4918

E-mail: marcin.kawko@doktorant.sgh.waw.pl 